\title{
Mekanisme Penentuan Nilai Ekonomis dan Pengikatan Hak Cipta Sebagai Objek Jaminan Fidusia
}

\author{
Reni Budi Setianingrum
}

DATA NASKAH

Masuk: 26 Juli 2016

Diterima: 30 Juli 2016

Terbit: 8 Desember 2016

KORESPONDEN PENULIS:

Fakultas Hukum Universitas Muhammadiyah Yogyakarta Jl. Lingkar Selatan, Kasihan, Bantul, Daerah Istimewa Yogyakarta

E-mail: rendi_rendy@yahoo.com

\section{ABSTRACT}

Act number 28 of 2014 on Copyright regulates that the Copyright as a movable intangible objects can be used as fiduciary transfer of ownership. Provisions regarding Copyright as the object of fiduciary transfer of oiwnership will be implemented in accordance with the provisions of the legislation applied. But practically, it is still being debated by many related parties, especially about valuation method and collateral binding mechanism, so recently there is no party that provides credit with collateral in the form of Copyright. This research used a normative juridical method and aims to study the valuation and binding mechanism of Copyright as fiduciary transfer of ownership's object collateral in Indonesia, by comparing with the methods used in Common Law countries.

Keywords: Copyright, Fiduciary Transfer Of Ownership, Valuation Method

\section{ABSTRAK}

Undang Undang nomor 28 tahun 2014 Tentang Hak Cipta mengatur bahwa Hak Cipta sebagai benda bergerak tidak berwujud dapat dijadikan sebagai objek jaminan fidusia. Ketentuan mengenai Hak Cipta sebagai objek jaminan fidusia akan dilaksanakan sesuai dengan ketentuan peraturan perundang-undangan yang berlaku. Akan tetapi pada kenyataannya, hal tersebut masih diperdebatkan oleh berbagai kalangan terkait, terutama mengenai mekanisme penilaian dan pengikatan jaminan, sehingga sampai saat ini belum ada pihak yang memberikan kredit dengan jaminan berupa Hak Cipta. Penelitian ini menggunakan metode yuridis normatif dan bertujuan untuk mempelajari mekanisme penilaian dan pengikatan Hak Cipta sebagai objek jaminan fidusia di Indonesia, dengan membandingkan dengan metode yang dilakukan di negara Common Law. 


\section{MEDIA
HUKUM}

Kata kunci: Hak Cipta, Jaminan Fidusia, Metode Penilaian

\section{PENDAHULUAN}

Pesatnya perkembangan ekonomi kreatif, teknologi informasi dan komunikasi di Indonesia mengharuskan adanya pembaruan pengaturan tentang Hak Cipta. Bercermin kepada negara-negara maju tampak bahwa perlindungan yang memadai terhadap Hak Cipta telah berhasil membawa pertumbuhan ekonomi kreatif secara signifikan dan memberikan kontribusi nyata bagi perekonomian dan kesejahteraan rakyat. (Eddy Damian, 2009:1)

Undang Undang Nomor 28 tahun 2014 tentang Hak Cipta dalam Pasal 16 ayat (3), mengatur bahwa Hak Cipta sebagai benda bergerak tidak berwujud dapat dijadikan sebagai objek jaminan fidusia. Hal ini berarti, lembaga keuangan baik bank maupun non bank akan menerima Hak Cipta sebagai sebuah agunan kredit.

Pada prakteknya, sampai dengan saat ini, belum ada lembaga keuangan manapun yang menjalankan ketentuan tersebut. Hal ini tentu saja terkait dengan pemberlakuan asas kehati-hatian bank, dimana bank harus mendapatkan kepastian pengembalian dana yang telah dipinjamkan kepada seniman.

Pada umumnya bank bersedia memberi utang kepada peminjam asalkan peminjam atau debitur menyediakan harta kekayaannya guna menjamin kelancaran utangnya. (http:// business-law.binus.ac.id/2015/10/08/hak-cipta-sebagaiobjek-jaminan-fidusia/ diakses pada tanggal 8 Maret 2016)

Pengaturan dalam Pasal 16 ayat (3) terkait dan bahkan tidak terlepas dengan ketentuan perundang-undang yang lain. Ketentuan perundang-undangan yang terkait dalam hal ini adalah undang-undang jaminan fidusia dan undangundang perbankan.(Rio F. Najoan, 2016:152)

Dalam hukum jaminan, penentuan jenis jaminan dipengaruhi oleh objek jaminannya. Apabila objeknya berupa barang tidak bergerak, khususnya tanah, jaminannya adalah hak tanggungan yang diatur dengan Undang Undang Nomor 4 Tahun 1996 tentang Hak Tanggungan. Untuk barang bergerak dikenal ada dua macam jaminan, yakni gadai dan fidusia. Pengaturan tentang gadai ada di dalam Pasal 1150 1161 KUHPerdata, sedangkan untuk fidusia sendiri diatur dalam Undang Undang Nomor 42 Tahun 1999 tentang Jaminan Fidusia.

Jika dilihat dari Pasal 1 butir 2 Undang Undang Jaminan Fidusia yang berbunyi sebagai berikut:

"Jaminan Fidusia adalah hak jaminan atas benda bergerak baik yang berwujud maupun yang tidak berwujud dan benda tidak bergerak khususnya bangunan yang tidak dapat dibebani hak tanggungan sebagaimana dimaksud dalam Undang-undang Nomor 4 Tahun 1996 tentang Hak Tanggungan yang tetap berada dalam penguasaan Pemberi Fidusia, sebagai agunan bagi pelunasan utang tertentu, yang memberikan kedudukan yang diutamakan kepada Penerima Fidusia terhadap kreditor lainnya."

Maka Hak cipta sudah memenuhi syarat yang ditentukan pada Pasal 1 butir 2 tersebut, namun praktisi lembaga keuangan di Indonesia masih menemui beberapa hambatan dalam pelaksanaannya. Hambatan-hambatan tersebut berkaitan dengan hal-hal tersebut di bawah ini, antara lain:

1. Nilai ekonomi dari suatu Hak Cipta,

2. Kepemilikan suatu Hak Cipta (terkait dengan Indonesia menganut prinsip deklaratif bukan prinsip konstitutif)

Hambatan-hambatan tersebut timbul karena belum adanya peraturan pelaksanaan yang khusus mengenai Hak Cipta sebagai objek jaminan fidusia. Keadaan tersebut menimbulkan resiko yang cukup besar bagi pihak perbankan untuk dapat menerima hak cipta sebagai suatu agunan. Hak Cipta merupakan benda bergerak tak berwujud (intangible) yang sampai saat ini belum ada pengaturan secara baku bagaimana menilai atau menaksir nilai ekonomis dari sebuah Hak Cipta.

Dapat disimpulkan bahwa dari kedua peraturan perundang-undangan terkait tersebut, Hak Cipta secara normatif dapat dijadikan sebagai objek jaminan fidusia. Akan tetapi pada prakteknya, Pasal 6 Undang Undang Nomor 42 Tahun 1999 tentang Jaminan Fidusia mengatur bahwa akta Jaminan Fidusia yang dibuat oleh Notaris, harus dicantumkan nilai penjaminan dan nilai benda yang dijadikan objek jaminan fidusia, hal ini membuat sebuah pertanyaan baru, darimana nilai benda tersebut diperoleh?

Berdasarkan latar belakang di atas, maka permasalahan penelitian ini dirumuskan adalah bagaimana mekanisme penentuan nilai ekonomi suatu Hak Cipta di Indonesia untuk 
dapat dijadikan Objek Jaminan Fidusia, apabila dibandingkan dengan praktek di negara penganut sistem Common Law?

\section{METODE PENELITIAN}

Penelitian ini merupakan penelitian yuridis normatif, dimana penelitian hukum normatif adalah penelitian hukum yang dilakukan dengan meneliti bahan kepustakaan primer berupa peraturan perundang-undangan.

Dalam penelitian ini, yang dikaji adalah ketentuan hukum positif mengenai Hak Cipta yaitu Undang Undang Nomor 28 tahun 2014 dan Undang Undang Nomor 42 Tahun 1999 tentang Jaminan Fidusia.

\section{PEMBAHASAN}

\section{A. Mekanisme Penentuan Nilai Ekonomis}

\section{Suatu Hak Cipta Apabila Hendak Dijadikan}

\section{Objek Jaminan Fidusia}

Salah satu aspek khusus pada Hak Kekayaan Intelektual, salah satu diantaranya Hak Cipta, adalah Hak Ekonomi (economic right), dimana Hak Ekonomi adalah Hak Untuk memperoleh keuntungan ekonomi atas kekayaan intelektual. (Abdulkadir Muhammad, 2007:23) Selain Hak Ekonomi, terdapat juga Hak Moral, yang diatur dalam Pasal 24, 25, 26 Undang Undang Hak Cipta Nomor 19 Tahun 2002 yang saat ini telah digantikan dengan Undang Undang Nomor 28 tahun 2014.

Menurut Abdulkadir Muhammad, salah satu hak khusus yang melekat terhadap Hak Kekayaan Intelektual termasuk diantaranya Hak Cipta, adalah Hak Ekonomi, yaitu hak untuk memperoleh keuntungan ekonomi atas kekayaan intelektual. Dikatakan Hak Ekonomi karena Hak Kekayaan Intelektual adalah benda yang dapat dinilai dengan uang. (Abdulkadir Muhammad, 2007:23)

Dalam Penjelasan Undang Undang Nomor 28 Tahun 2014 tentang Hak Cipta, mengatur beberapa hal yang berbeda dari Undang Undang Nomor 19 Tahun 2002, antara lain:

a) Perlindungan Hak Cipta dilakukan dengan waktu lebih panjang untuk Hak Cipta di bidang tertentu, yaitu diberlakukan selama hidup pencipta ditambah 70 (tujuh puluh) tahun setelah pencipta meninggal dunia; b) Penyelesaian sengketa secara efektif melalui proses mediasi, arbitrase atau pengadilan, serta penerapan delik aduan untuk tuntutan pidana; dan

c) Hak Cipta sebagai benda bergerak tidak berwujud dapat dijadikan objek jaminan fidusia.

Dalam Undang Undang Hak Cipta yang baru, telah diatur sebuah ketentuan baru yang menambah nilai ekonomi dari suatu Hak Cipta, yaitu dimana Hak Cipta sebagai benda bergerak tidak berwujud (intangible) dapat dijadikan objek Jaminan Fidusia. Hal ini sesuai dengan pendapat Sudjana bahwa lembaga penjaminan yang paling memungkinkan dibebankan kepada Hak Cipta sebagai obyek jaminan hutang adalah lembaga jaminan fidusia mengingat Hak Cipta merupakan benda bergerak. (Sudjana, 2012:407)

Akan tetapi ketentuan dalam Undang Undang ini menyisakan banyak pekerjaan rumah, terutama dari pihak pemberi kredit dalam mementukan nilai ekonomis agunan, dikarenakan Hak Cipta merupakan benda tidak berwujud (intangible asset), dalam akuntansi disebut sebagai aktiva tak berwujud, dimana aktiva tak berwujud merupakan nonmonetary asset yang tidak memiliki wujud fisik yang terdapat dalam neraca perusahaan, yang digunakan untuk memproduksi barang dan jasa. (Lisvery, 2004:1)

Undang Undang Nomor 42 Tahun 1999 tentang Fidusia, menyatakan bahwa fidusia adalah pengalihan hak kepemilikan suatu benda atas dasar kepercayaan dengan ketentuan bahwa benda yang hak kepemilikannya dialihkan tersebut tetap dalam penguasaan pemilik benda, sedangkan Jaminan Fidusia adalah hak jaminan atas benda bergerak baik yang berwujud maupun yang tidak berwujud dan benda tidak bergerak khususnya bangunan yang tidak dapat dibebani hak tanggungan sebagaimana dimaksud dalam Undang-undang Nomor 4 Tahun 1996 tentang Hak Tanggungan yang tetap berada dalam penguasaan Pemberi Fidusia, sebagai agunan bagi pelunasan utang tertentu, yang memberikan kedudukan yang diutamakan kepada Penerima Fidusia terhadap kreditor lainnya.

Berbicara tentang jaminan, umumnya selalu dihubungkan dengan pemberian kredit atau pembiayaan. M. Syafi'l Antonio menjelaskan bahwa pembiayaan merupakan salah satu tugas pokok bank yaitu pemberian fasilitas dana untuk memenuhi kebutuhan pihak-pihak yang 


\section{MEDIA
HUKUM}

merupakan deficit unit. (Antonio, 2001:160) Menurut Undang-undang perbankan No 10 tahun 1998 adalah penyediaan uang atau tagihan yang dapat dipersamakan dengan itu, berdasarkan persetujuan atau kesepakatan antara bank dengan pihak lain yang mewajibkan pihak yang dibiayai mengembalikan uang atau tagihan tersebut setelah jangka waktu tertentu dengan imbalan atau bagi hasil. (Kasmir, 2002:73)

Suatu lembaga keuangan baik maupun bukan bank, termasuk lembaga pembiayaan, didalam memberikan kredit atau pembiayaan umumnya meminta jaminan kepada debitur. Jaminan yang dimaksud disini bisa jaminan kebendaan maupun jaminan perorangan.

Istilah Jaminan, merupakan terjemahan dari bahasa Belanda "zekerheid" atau cautie, mencakup secara umum cara-cara kreditur dipenuhi tagihannya, disamping pertanggung jawaban debitur terhadap barang-barangnya. (Salim HS, 2005:5-6) Menurut Oey Hoey Tiong, istilah jaminan berasal dari kata "Jamin" yang berarti tanggung, sehingga jaminan dapat diartikan sebagai tanggungan. (Tiong, 1983:14)

Jaminan fidusia merupakan jaminan khusus yang timbul karena adanya suatu perjanjian khusus antara debitur dengan kreditur dan dapat dieksekusi tanpa melalui putusan pengadilan (parate eksekusi) dikarenakan pada kepala Akta Jaminan Fidusia sudah tertulis titel eksekutorial berupa irahirah, yaitu kalimat "Demi Keadilan Berdasarkan Ketuhanan Yang Maha Esa". Di Indonesia, jaminan fidusia diatur dengan Undang Undang Nomor 42 tahun 1999 tentang Jaminan Fidusia (UUJF).

Sebelum lahirnya Undang Undang jaminan Fidusia selanjutnya disebut UUJF, masih terdapat perbedaan pendapat diantara para ahli hukum mengenai sifat perjanjian jaminan fidusia.(Supianto, 2015:124) Pendapat pertama mengatakan bahwa perjanjian jaminan fidusia bersifat accessoir sesuai dengan sifat yang melekat pada hukum jaminan gadai dan hipotek. Pendapat kedua mengatakan bahwa perjanjian jaminan fidusia merupakan perjanjian yang bersifat berdiri sendiri (zelfstanding).(Tan Kamelo, 2006:193)

Sifat accessoir perjanjian jaminan Fidusia dinyatakan dalam Pasal 4 UUJF yang berbunyi "jaminan Fidusia merupakan perjanjian ikutan dari suatu perjanjian pokok bukan kewajiban bagi para pihak untuk memenuhi prestasi". (Supianto, 2015:124) Akibat dari sifat ikutan fidusia adalah bahwa jaminan fidusia hapus demi hukum bilamana utang yang dijamin dengan jaminan fidusia hapus. (J.Satrio, 2000:128)

Dalam fidusia, objek jaminan tidak dikuasai oleh kreditur dan tetap dalam penguasaan debitur, serta tidak disertai penyerahan fisik. Perjanjian fidusia dilakukan secara tertulis dalam bentuk akta notaris dan wajib pula dilakukan pendaftaran pada Kantor Pendaftaran Fidusia. Setelah pendaftaran baru akan lahir jaminan fidusia.

Dengan demikian apabila suatu hak cipta akan dijadikan sebagai jaminan fidusia, maka suatu ciptaan itu harus didaftarkan terlebih dahulu di Direktorat Jenderal Kekayaan Intelektual. Agar jelas apabila terjadi wanprestasi, bahwa pemberi fidusia adalah pemegang Hak Cipta dan pelaksanaan eksekusi dapat dilakukan tanpa harus melalui putusan pengadilan.

Benda-benda yang dapat dibebani dengan jaminan fidusia adalah sebagai berikut: (Fuady, 2003:23)

1. Benda tersebut dapat dimiliki dan dialihkan secara hukum

2. Benda berwujud, atau benda tidak berwujud termasuk piutang

3. Benda bergerak dan benda tidak bergerak

4. Benda yang sudah ada maupun benda yang akan diperoleh kemudian

5. Dapat atas satu satuan atau jenis benda

6. Dapat juga atas lebih dari satu jenis atau satuan benda

7. Termasuk hasil dari benda yang telah menjadi objek jaminan fidusia termasuk juga hasil klaim asuransi dari benda yang telah menjadi objek jaminan fidusia

8. Benda persediaan (inventory, stock perdagangan)

Pemberi fidusia adalah orang perorangan atau koorporasi pemilik benda yang menjadi obyek jaminan fidusia, sedangkan penerima fidusia adalah orang perorangan atau koorporasi yang mempunyai piutang yang pembayarannya dijamin dengan jaminan fidusia. (Salim HS, 2011:128)

Mekanisme pengikatan jaminan fidusia menurut UUJF dapat diringkas sebagai berikut:

1. membuat akta Jaminan Fidusia di hadapan Notaris;

2. akta tersebut di daftarkan di Kantor Pendaftaran Fidusia, yang merupakan bagian dari Direktorat Administrasi 
Hukum Umum, Kementerian Hukum dan Hak Asasi Manusia;

3. membayar biaya pendaftaran Jaminan Fidusia

4. penerbitan Sertifikat Jaminan Fidusia yang memuat titel eksekutorial

5. Dalam Akta Jaminan Fidusia dan Sertifikat Jaminan Fidusia, termuat nilai benda dan nilai penjaminan dari objek Jaminan Fidusia tersebut.

Dalam mekanisme penilaian benda yang akan dijadikan agunan dan dibebani dengan lembaga penjaminan, praktek yang selama ini lazim terjadi di lapangan, lembaga keuangan pemberi kredit (kreditur), menggunakan jasa Penilai Publik yang lazim disebut appraisal. Penilai Publik adalah pihak ketiga yang merupakan profesi penunjang di sektor keuangan, dan dapat memberikan pertimbangan profesional mengenai penilaian nilai ekonomi benda, yang kemudian akan dibebani dengan lembaga jaminan.

Profesi Penilai Publik ini diatur dengan Peraturan Menteri Keuangan Republik Indonesia Nomor 101/PMK.01/2014 tentang Penilai Publik. Dalam peraturan ini, Penilai adalah seseorang yang memiliki kompetensi dalam melakukan kegiatan Penilaian, yang sekurang-kurangnya telah lulus pendidikan awal Penilaian, dan Penilai Publik adalah Penilai yang telah memperoleh izin dari Menteri untuk memberikan jasa sebagaimana diatur dalam Peraturan Menteri tersebut.

Kewenangan Penilai Publik meliputi bidang jasa Penilaian sebagai berikut:

a) Penilaian Properti Sederhana;

b) Penilaian Properti; dan

c) Penilaian Bisnis.

Penilaian terhadap suatu Hak Cipta termasuk dari bagian bidang jasa Penilaian Bisnis yang meliputi:

a) entitas bisnis;

b) penyertaan;

c) surat berharga termasuk derivasinya;

d) hak dan kewajiban perusahaan;

e) aset tak berwujud;

f) kerugian ekonomis yang diakibatkan oleh suatu kegiatan atau peristiwa tertentu untuk mendukung berbagai tindakan korporasi atau atas transaksi material;

g) opini kewajaran; dan

h) instrumen keuangan.
Dalam melakukan penilaian, Penilai Publik menggunakan Standar Penilaian Indonesia yang selanjutnya disingkat SPI. SPI adalah pedoman dasar yang wajib dipatuhi oleh Penilai dalam melakukan Penilaian.

Adapun prosedur dan mekanisme penilaian yang dilaksanakan oleh Penilai Publik sesuai Pasal 4 Peraturan Menteri Keuangan Republik Indonesia Nomor 101/PMK.01/ 2014 tentang Penilai Publik adalah sebagai berikut:

1. mengidentifikasi dan memahami lingkup penugasan;

2. melakukan pengumpulan, pemilihan dan analisis data;

3. menerapkan pendekatan Penilaian; dan

4. menyusun Laporan Penilaian.

Tahapan penilaian aset oleh Penilai Publik, diambil dari website resmi salah satu kantor Penilai Publik adalah sebagai berikut:(http://bit.ly/1Urdl0a, diakses 16 Juni 2016)

1. Persiapan

2. Survey lapangan (dokumentasi aset, pencarian data)

3. Analisa, dengan menggunakan metode:

a) pendekatan data pasar atau sering disebut juga sebagai metode perbandingan harga jual (sales comparation method) atau metode perbandingan data langsung (direct market comparation method) adalah metode penilaian yang dilakukan dengan cara membandingkan secara langsung properti yang dinilai dengan data properti yang sejenis;

b) pendekatan biaya, mengunakan Metode Kalkulasi biaya, Nilai properti (Tanah dan Bangunan) diperoleh dengan menganggap tanah sebagai tanah kosong, nilai tanah dihitung dengan menggunakan metode perbandingan data pasar (market data approach). Sedangkan nilai bangunan dihitung dengan metode kalkulasi Biaya; dan

c) pendekatan pendapatan, dimana nilai dari properti tergantung pada kemampuan properti itu untuk menghasilkan keuntungan.

4. Rekap hasil

5. Pembuatan laporan akhir

Saat ini, untuk menentukan nilai dari objek berupa tanah dan bangunan, Penilai Publik menggunakan nilai pasar (market value) yang wajar di wilayah tempat tanah dan bangunan tersebut berada. Nilai Pasar didefinisikan sebagai estimasi sejumlah uang pada tanggal penilaian, yang dapat diperoleh 


\section{MEDIA
HUKUM}

dari transaksi jual beli atau hasil penukaran suatu properti, antara pembeli yang berminat membeli dengan penjual yang berminat menjual, dalam suatu transaksi bebas ikatan, yang pemasarannya dilakukan secara layak, di mana kedua pihak masing-masing bertindak atas dasar pemahaman yang dimilikinya, kehati-hatian dan tanpa paksaan. (3.1. SPI 1, Standar Penilaian Indonesia I 2007)

Untuk agunan berupa benda tidak berwujud berupa piutang, nilai bendanya sama dengan besar piutangnya. Nilainilai tersebut akan dicantumkan dalam laporan penilaian dan kemudian akan digunakan oleh lembaga keuangan pemberi pinjaman atau kreditur sebagai dasar pemberian nominal kredit.

Menurut ketentuan 15 /PBI/2012 Tentang Penilaian Kualitas Aset Bank Umum Pasal 43, agunan yang dapat diperhitungkan ditetapkan sebagai berikut:

a. Surat Berharga dan saham yang aktif diperdagangkan di bursa efek di Indonesia atau memiliki peringkat investasi dan diikat secara gadai;

b. tanah, gedung, dan rumah tinggal yang diikat dengan hak tanggungan;

c. mesin yang merupakan satu kesatuan dengan tanah yang diikat dengan hak tanggungan;

d. pesawat udara atau kapal laut dengan ukuran di atas 20 (dua puluh) meter kubik yang diikat dengan hipotek;

e. kendaraan bermotor dan persediaan yang diikat secara fidusia; dan/atau

f. resi gudang yang diikat dengan hak jaminan atas resi gudang.

Sertifikat Hak Kekayaan Intelektual saat ini belum termasuk dalam daftar agunan yang dimaksud oleh otoritas Bank Indonesia.

Selain belum tercantum dalam daftar agunan, untuk Hak Cipta, sampai saat ini belum ada pedoman penilaian yang dapat digunakan oleh Penilai Publik, sehingga tentu saja belum ada lembaga keuangan yang menerima Hak Cipta sebagai agunan. Peraturan pemerintah yang mengatur lebih lanjut mengenai mekanisme pembebanan fidusia kepada Hak Cipta juga belum ada.

Kita dapat belajar dari Amerika Serikat yang dalam Copyright Law of the United States and Related Laws Contained in Týtle 17 of the United States Code, telah mengatur bahwa salah satu pengalihan Hak Cipta adalah dengan melalui penjaminan atau lazim di sebut Mortgage, seperti yang termuat dalam ketentuan Definitions, Subject Matter and Scope of Copyright, yang berbunyi:

"A "transfer of copyright ownership" is an assignment, mortgage, exclusive license, or any other conveyance, alienation, or hypothecation of a copyright or of any of the exclusive rights comprised in a copyright, whether or not it is limited in time or place of effect, but not including a nonexclusive license." (Copyright Law of the United States and Related Laws Contained in Týtle 17 of the United States Code)

Untuk menentukan nilai Royalty Fee, sudah dibentuk sebuah lembaga khusus yang berkompeten yaitu Royalty Judges yang berwenang untuk mengatur segala hal yang terkait dengan Royalty Fee, hak dan kewajiban pihak yang terkait dengan penggunaan Hak Cipta, termasuk diantaranya sanksi bagi pihak yang tidak memenuhi kewajiban membayar Royalty Fee.

Di Indonesia, lembaga sejenis sudah diatur oleh Undang Undang Hak Cipta yang baru, yaitu berupa Lembaga Manajemen Kolektif (LMK), Lembaga Manajemen Kolektif adalah institusi yang berbentuk badan hukum nirlaba yang diberi kuasa oleh Pencipta, Pemegang Hak Cipta, dan/atau pemilik Hak Terkait guna mengelola hak ekonominya dalam bentuk menghimpun dan mendistribusikan royalti.

LMK ini dapat membantu upaya Penilai Publik dalam menilai sebuah Hak Cipta, yaitu dengan memberikan data resmi berupa besaran royalti yang diterima oleh pemegang Hak Cipta selama jangka waktu tertentu, untuk digunakan sebagai salah satu dasar pertimbangan nilai ekonomis Hak Cipta.

Selain nilai ekonomis suatu Hak Cipta, menentukan siapa yang berhak sebagai Pemberi Fidusia juga tidak mudah. Meskipun perlindungan terhadap Hak Cipta menganut sistem deklaratif atau perlindungan tidak mensyaratkan pendaftaran, akan tetapi guna melindungi Hak Ekonomi atas karya ciptanya, maka para pencipta harus mendaftarkan Hak Cipta kepada Direktorat Jenderal Hak Atas Kekayaan Intelektual Kementerian Hukum dan Hak Asasi Manusia sebagai salah satu kepastian hukum siapakah pihak yang berhak menjaminkan suatu Hak Cipta. 
Dari uraian di atas, sehubungan dengan belum adanya peraturan perundang-undangan yang mengatur lebih lanjut mengenai mekanisme pembebanan fidusia terhadap Hak Cipta, ada beberapa kriteria yang dapat digunakan sebagai dasar penilaian nilai ekonomis sebuah Hak Cipta untuk dapat dijadikan agunan kredit, antara lain:

a) Hak Cipta harus sudah terdaftar pada Direktorat Jenderal Hak Kekayaan Intelektual Kementerian Hukum dan Hak Asasi Manusia

b) Hak Cipta tersebut sudah memiliki estimasi nilai ekonomis yang dapat dipertanggungjawabkan, dapat dilihat dari nilai kontrak dengan perusahaan yang menggunakan/ menyebarluaskan/ mendistribusikan/ menampilkan karya cipta tersebut

c) Hak Cipta tersebut sudah dikelola oleh Lembaga Manajemen Kolektif, sehingga nilai royaltinya sudah dapat diketahui

d) Pemberian Kredit diberikan dalam asas kehati-hatian, dalam artian besaran nilai kredit, peruntukan dan jangka waktu harus sesuai dengan ketentuan Bank Indonesia dan atau Otoritas Jasa Keuangan

e) Sertifikat Hak Kekayaan Intelektual sudah termasuk dalam jenia agunan yang diperbolehkan dalam pembiayaan kredit bank

f) Jika diperlukan maka diberikan jaminan lain berupa personal guarantee atau borgtocht dari perusahaan yang menaungi sebuah karya cipta tersebut (misalkan personal guarantee dari pemilik perusahaan label musik yang menaungi seorang pencipta lagu).

\section{B. Mekanisme penilaian nilai ekonomis dari} suatu benda tidak berwujud dalam praktek di negara Common Law

Di negara industri maju, Hak Kekayaan Intelektual telah dikembangkan sebagai agunan/collatera/ diantara bendabenda lainnya sebagai jaminan bagi pemberian pembiayaan kredit. Contohnya di China, Cina telah meluncurkan proyek percontohan nasional untuk memberikan pinjaman kepada perusahaan yang memenuhi syarat untuk menggunakan hak kekayaan intelektual (HKI) seperti paten sebagai jaminan. Enam lembaga pinjaman Cina, termasuk Industri dan Com- mercial Bank of China dan China Construction Bank, menandatangani perjanjian HKI senilai 1.308.000.000 yuan (\$ 186.860.000) dalam bentuk pinjaman kepada 18 perusahaan. The State Intellectual Property Office (SIPO) memutuskan untuk memulai proyek serupa di kota-kota termasuk Beijing dan Shanghai. Padahal sebelumnya, perbankan di Cina menawarkan pinjaman dengan jaminan hipotek terutama pada aset berwujud seperti pabrik dan peralatan. (Akhmad Junaidi dan Muhammad Joni, 2011:126)

Selain di China, pemberian pembiayaan dengan jaminan Hak Kekayaan Intelektual telah diatur di negara lain, misalnya di Amerika Serikat, Developer Software bisa memperoleh pembiayaan dari lembaga keuangan. (http:// www.hukumonline.com/berita/baca/lt542addced8dff/ seniman-bisa-menjaminkan-karyanya-untuk-berutang-dibank, diakses pada tanggal 15 Juni 2016)

Konsep jaminan dalam perbankan di dunia, sebagaimana yang dikemukakan oleh Steven Emanuel dan Ray D. Henson mengindikasikan bahwa collateral dapat dikatakan merupakan bagian dari konsep security. (Rahmatullah, 2015:78) Bentuk security ada tiga, yaitu Mortgage (Dalam Kamus Bank Indonesia, mortgage dipersamakan dengan hipotek, yaitu instrumen utang dengan pemberian hak tanggungan atas properti dan peminjam kepada pemberi pinjaman sebagai jaminan terhadap kewajibannya; dalam hal ini peminjam masih dapat menggunakan atau memanfaatkan properti tersebut; hak tanggungan atas properti gugur setelah kewajibannya dibayar lunas), Pledge (Gadai), dan Lien. (Dalam Kamus Bank Indonesia, dipersamakan dengan Hak Gadai, yaitu Hak kreditur atas harta tertentu sebagai jaminan piutangnya).

Dalam security, ada dua jenis konsep property yang dapat digunakan sebagai jaminan pinjaman, yaitu Real Property dan Personal Property. Real Property selalu dikaitkan dengan kepemilikan tanah (freehold land). Sedangkan Personal Property dikaitkan dengan pemegang sewa tanah (leasehold land) dan segala benda yang bergerak termasuk chattels (Dalam kamus Bank Indonesia, chattel didefinisikan sebagai hak pemanfaatan atas agunan debitur oleh kreditur) dan choses (Chose in action, hak untuk menuntut suatu pemenuhan kewajiban atau pemilikan atas barang atau uang berdasarkan perikatan tertentu, seperti hak paten dan hak 


\section{MEDIA
HUKUM}

cipta; hak tuntut digolongkan sebagai barang bergerak yang tidak berwujud).

Hak Kekayaan Intelektual merupakan bagian dari choses in action, yaitu merupakan properti yang secara fisik tidak terlihat sehingga tidak dapat dilindungi dari segi fisiknya dan oleh karena itu membutuhkan penetapan pengadilan. Istilah tersebut digolongkan sebagai properti yang tak berwujud atau intangible property yang dapat dicontohkan seperti cek, bukti kepemilikan hak paten, hak cipta, dan lain-lain. (Rahmatullah, 2015:79)

Untuk dapat dilakukan penilaian secara ekonomis (economic valuation), maka Hak Cipta harus memenuhi syarat antara lain: (Module 11, Intellectual Property Valuation, World Intellectual Property Organization: 8)

1) Sebuah karya cipta harus dapat diidentifikasi secara spesifik dan dapat dikenali;

2) Harus ada bukti nyata atau manifestasi dari keberadaan karya cipta tersebut (misalnya, kontrak, lisensi, dokumen pendaftaran, disket komputer, satu set dokumentasi prosedural, daftar pelanggan, direkam pada satu set laporan keuangan, dll);

3) Karya cipta itu harus telah dibuat/ telah ada;

4) Karya cipta tersebut harus memiliki perlindungan hukum dan dapat dialihkan secara sah;

5) Karya cipta tersebut harus memiliki nilai jual

Terkait dengan pemberian pembiayaan dengan jaminan Hak Kekayaan Intelektual yang merupakan intangible asset, praktek di Amerika Serikat, terdapat beberapa mekanisme.

\section{Pembiayaan Produksi Film}

Dalam pembiayaan untuk suatu produksi film, maka disini produser film bertindak sebagai debitur. Akan tetapi bank akan memprioritaskan distributor film sebagai sumber pembayaran. Meskipun distributor film merupakan sumber pembayaran, produser tetap harus bertanggung jawab atas hutang tersebut apabila terjadi gagal bayar oleh distributor. Sebagai syarat untuk meminjamkan uang kepada produsen, bank mewajibkan produser untuk menyerahkan ke bank hak untuk menerima pembayaran dari distributor sesuai dengan perjanjian distribusi. (Eshman, 1992:88)

Bank "mengurangi" nilai perjanjian distribusi untuk menentukan jumlah nilai pinjaman produser, "pengurangan" nilai perjanjian distribusi melibatkan analisis perjanjian untuk menentukan jumlah minimum yang harus dibayar oleh distributor, penentuan keadaan di mana distributor akan dibebaskan dari kewajiban pembayaran, dan penilaian kelayakan kredit distributor. Kredit tergantung pada, antara lain apakah distributor adalah sebuah studio besar atau sebuah perusahaan produksi independen. Jika bank merasa belum cukup aman, bank meminta distributor untuk mendapatkan jaminan tambahan berupa surat stand-by Letter of Credit dimana bank sebagai penerima. Pada pokoknya, nilai perjanjian hak distribusi sudah dapat mencerminkan kelayakan kredit dari distributor. Setelah bank menentukan jumlah minimum yang harus dibayar oleh distributor ke produser, keadaan di mana distributor akan dibebaskan dari kewajiban pembayaran, dan kredit distributor, bank menentukan jumlah pembiayaan.

Dapat kita simpulkan bahwa untuk pembiayaan sebuah produksi film, maka jaminannya berupa hak distribusi film tersebut (apabila diperlukan maka ada jaminan tambahan berupa Letter of Credit), dan nilai pembiayaan ditentukan berdasarkan nilai perjanjian distribusi film.

\section{Penentuan nilai ekonomis Hak Cipta}

Dari perspektif ekonomi, aset tidak berwujud terkait hak cipta memiliki karakteristik ekonomi dan hukum yang mirip dengan jenis lain dari Hak Kekayaan Intelektual yang meliputi: merek dagang, paten, dan rahasia dagang. (Gilbert, 2009:35)

Tiga metode yang berlaku umum untuk penilaian jaminan juga dapat berlaku bagi penilaian Hak Kekayaan Intelektual dan dapat juga berlaku untuk analisis Hak Cipta. Pendekatan biaya yang kurang umum digunakan daripada pendekatan pendapatan atau pendekatan pasar. Karena hak cipta memberikan hak monopoli kepada pemilik, pendekatan biaya tidak selalu berlaku untuk analisis penilaian hak cipta. (Gilbert, 2009:39) Metode tersebut yaitu:

a) Metode pendekatan biaya

Penilaian ini didasarkan pada biaya yang dikeluarkan dalam mengembangkan atau menciptakan suatu karya cipta, atau biaya untuk menciptakan atau mengembangkan produk atau layanan serupa, tanpa mempertimbangkan nilai ekonomi dari karya cipta tersebut. Prinsip ini menyatakan bahwa nilai suatu obyek atau bagian dari kekayaan intelektual 
tidak lebih besar daripada biaya untuk memproduksinya. (http://www.consor.com/intellectual-property-advice/methods-used-to-value-ip-and-ia.html, diakses pada tanggal 16 Juni 2016)

Mengenai komponen biaya, banyak variasi yang dapat disertakan, mulai dari biaya tenaga kerja, biaya pendaftaran perlindungan Hak Kekayaan Intelektual, juga biaya pemasaran dan biaya "lunak" yaitu biaya waktu. (betterbusinessfinance.co.uk/images/pdfs/Valuing_your_Intellectual_Property.pdf:12)

Pendekatan biaya memang memiliki keterbatasan tertentu dalam menganalisis nilai ekonomis suatu hak cipta. Karena keterbatasan ini, pendekatan biaya sering dianggap hanya dapat memberikan patokan bagi estimasi nilai ekonomi terendah. (Gilbert, 2009:39)

b) Metode Pendekatan Nilai Pasar

Metode pendekatan pasar merupakan metode dimana Hak Kekayaan Intelektual atau aset tidak berwujud dinilai dengan membandingkannya dengan penjualan baru-baru ini, transfer, dan transaksi yang melibatkan aset yang sama di pasar yang sama.

Kendala dari metode pendekatan nilai pasar ini adalah kesulitan untuk menganalisa berapa nilai jual suatu karya cipta. Dengan kata lain, sulit untuk mengkonversi data berapa harga "per gambar", "per lirik", atau "per kata". Selain itu, pendekatan pasar untuk penilaian telah digunakan dengan aset berwujud mana pasar telah ada selama beberapa dekade, di bidang-bidang seperti real estate, peralatan, dan bahan baku. Namun, aset yang tidak berwujud, setidaknya sampai saat ini, belum dibeli dan dijual cukup sering untuk dapat membangun nilai semata-mata berdasarkan perbandingan nilai pasar langsung; Oleh karena itu, analisis dan penyesuaian hampir selalu diperlukan. Selain itu, transaksi aset tak berwujud sering dirahasiakan nilainya.

c) Metode Pendekatan Pendapatan

Metode pendekatan pendapatan menentukan nilai ekonomi berdasarkan pendapatan masa depan yang dapat, atau akan, dihasilkan dari kekayaan intelektual atau aset tidak berwujud. Pendekatan pendapatan bagi Hak Kekayaan intelektual merupakan metode penilaian yang digunakan secara luas; namun, hal itu dapat menjadi kompleks, karena harus memutuskan bagaimana mengukur "pendapatan".
Tiga parameter dasar dari pendekatan pendapatan adalah: (http://www.consor.com/intellectual-property-advice/methods-used-to-value-ip-and-ia.html, diakses pada tanggal 16 Juni 2016)

a) aliran pendapatan masa depan

b) durasi aliran pendapatan

c) tingkat risiko atau pengurangan yang mungkin terjadi

Ada beberapa metode lain, seperti The Brand Value Equation Methodology, The Competitive Advantage Technique, dan pendekatan royalti, akan tetapi ketiga metode di atas adalah metode yang paling umum di gunakan di negaranegara penganut sistem common law seperti Amerika Serikat dan Inggris.

\section{SIMPULAN}

Berdasarkan uraian di atas, dapat disimpulkan beberapa poin dalam kajian ini:

1. Untuk dapat mewujudkan misi pemerintah untuk meningkatkan nilai ekonomi dari Hak Cipta, tidak sematamata hanya dengan menerbitkan pengaturan mengenai Hak Cipta dapat dijadikan objek Jaminan Fidusia, akan tetapi pemerintah juga harus mengkoordinasikan instansi yang terkait dengan hal tersebut antara lain Bank Indonesia, Direktorat Jenderal Hak Kekayaan Intelektual, Lembaga Manajemen Kolektif, para pencipta, seniman dan asosiasi Penilai Publik Indonesia. Hal tersebut agar pada pelaksanaan di lapangan tidak terjadi kendala.

2. Di negara-negara common law memiliki metode penilaian yang sama antara benda berwujud (tangible asset) dan benda tak berwujud (intangible asset), yaitu Metode Pendekatan Biaya (Cost Approach Method), Metode Pendekatan Nilai Pasar (Market Value Method), dan Pendekatan Pendapatan (Income Approach Method) akan tetapi dengan beberapa analisis tambahan bagi penilaian aset tidak berwujud.

\section{DAFTAR PUSTAKA}

\section{Buku}

Damian, Eddy., Hukum Hak Cipta, Cetakan ke-1 Edisi ketiga, Bandung: PT Alumni, 2009

Fuady, Munir. Jaminan Fidusia, Bandung: Citra Aditya Bakti, 2003 
HS, Salim. Perkembangan Hukum Jaminan di Indonesia, edisi II, Jakarta: RajaGrafindo Persada, 2005 Pengantar Hukum Perdata Tertulis (BW), Cetakan ketujuh, Jakarta: Sinar Grafika, 2011

Indra Rahmatullah, Aset Hak Kekayaan Intelektual Sebagai Jaminan dalam Perbankan, Yogyakarta: Deepublish Publisher, 2015

J. Satrio, Hukum Jaminan Hak Jaminan Kebendaan Fidusia, Bandung: Citra Aditya Bakti, 2000

Kasmir, Manajemen Perbankan, Jakarta: PT Raja Grafindo Persada, 2002

Muhammad, Abdulkadir., Kajian Hukum Ekonomi Hak Kekayaan Intelektual Bandung: Citra Aditya Bakti, 2007

Muhammad Syafi I Antonio, Bank Syariah dari Teori ke Praktik, Jakarta: Gema Insani Press, 2001

Oey Hoey Tiong, Fidusia Sebagai Jaminan Unsur-unsur Perikatan, Jakarta; Ghalia Indonesia, 1983

Supianto, S.H., M.H. Hukum Jaminan Fidusia: Prinsip Publisitas pada Jaminan Fidusia, Yogyakarta; Penerbit Garudhawaca, 2015

Tan Kamelo, Hukum Jaminan Fidusia Suatu Kebutuhan Yang Didambakan, Bandung; Penerbit Alumni, 2006

\section{Perundang Undangan}

Undang Undang Nomor 42 Tahun 1999 tentang Jaminan Fidusia

Undang Undang Nomor 19 Tahun 2002 tentang Hak Cipta

Undang Undang Nomor 28 Tahun 2014 tentang Hak Cipta

Copyright Law of the United States and Related Laws Contained in Týtle 17 of the United States Code

Peraturan Menteri Keuangan Republik Indonesia Nomor 101/PMK.01/2014 tentang Penilai Publik

Standar Penilaian Indonesia I 2007

\section{Makalah}

Akhmad Junaidi dan Muhammad Joni, Pemanfaatan Sertifikat HKI Sebagai Collateral Kredit, Jurnal SMECDA Volume 6, September 2011

Jill Mazirow Eshman, Bank Financing of a Motion Picture, Loyola Marymount University and Loyola Law School, 1992

Katherine A. Gilbert, The Valuation of Copyright Related
Intangible Assets, Insights, 2009

Lisvery, Saoria, Aktiva Tak Berwujud, Jurnal Akuntansi dan Keuangan Indonesia, Departemen Akuntansi FEUI, 2004

Najoan, Rio F, Kajian Hukum Tentang Hak Cipta Sebagai Jaminan Fidusia, Lex et Societatis, Universitas Sam Ratulangi, 2016

Sudjana, Hak Cipta Sebagai Jaminan Kebendaan Bergerak Dikaitkan Dengan Obyek pengembangan Fidusia, Mimbar Hukum Volume 24, Nomor 3, Oktober 2012

Module 11, Intellectual Property Valuation, World Intellectual Property Organization

\section{Internet}

http://business-law.binus.ac.id/2015/10/08/hak-ciptasebagai-objek-jaminan-fidusia/

http://bit.ly/1Urdloa,

http://www.hukumonline.com/berita/baca/ 1t542addced $8 \mathrm{dff} /$ seniman-bisa-menjaminkankaryanya-untuk-berutang-di-bank,

http://www.consor.com/intellectual-property-advice/ methods-used-to-value-ip-and-ia

http://betterbusinessfinance.co.uk/images/pdfs/ Valuing_your_Intellectual_Property 